\title{
Discussion on the Countermeasures of Rural Information Service in Agricultural Colleges and Universities
}

\author{
Haixia Wang \\ Jilin Agricultural Science and Technology University, Jilin Province, China \\ 493729327@qq.com, 356894743@qq.com
}

Keywords: Agricultural university; Library; Rural information service

\begin{abstract}
The library of higher agricultural colleges serves the rural economic construction, which is the need to adapt to the socialist market economy and realize its own value.This paper expounds the advantages and necessities of Agricultural University Library Facing the rural information service, and expounds the specific countermeasures for the rural information service.
\end{abstract}

\section{Introduction}

The construction of new countryside is the most important part of China's current economic development, and the rural information service construction has a direct impact on the rural economic. With the development of rural economy, how to carry out and implement rural information service has become a concern of all circles. The library of agricultural colleges is supposed to serve the rural economic construction, as a part of social welfare and cultural institutions. We should keep pace with the times, give full play to our resource advantages and values, and propose and improve the information suitable for the new countryside, New ideas and methods for the development of agricultural informationization and the sustainable development of agricultural university libraries, which has an important role to play, in view of the different information needs of different social groups in the new rural construction, in the new countryside.

\section{The Advantages of Agricultural University Library for Rural Information Service}

The library of higher agricultural colleges, as the school's literature and information center, has unique advantages in providing information service for rural areas, mainly in the following four aspects:

Firstly, it is the collection of various literature resources of the library, which brings a wide range of scientific and technological intelligence information, which is more than the general public library. Among these literature resources, many kinds are directly related to rural economic development, and can be used directly for rural economic development, which can produce economic and social benefits quickly. The library of higher agricultural institutions is the important material foundation for the rural information service.

Secondly, there is a number of good business management personnel, college also has all kinds of experts, professors, some of them take on national and provincial major scientific research project for a long time, collected a large amount of high level science and technology in the study of literature, and mastered a lot of live intelligence information, is a very important intelligence force, as the intellectual resources, in the higher agricultural colleges and universities library[1].

Thirdly, there are more advanced information transmission equipment in the library of higher agricultural university, such as electronic computer, microcomputer, photocopy, etc., which can send various intelligence information to the outside accurately.

Fourth, close collaborative relationship with domestic and foreign is established, and a crisscross information distribution network is formed, in the higher agricultural colleges and universities library with literature communication and academic exchanges. The intelligence information is more accuracy, higher authority from the agricultural colleges, compared with some information on the social sector. 


\section{The Necessity of Rural Information Service for Agricultural Colleges and Universities}

First of all, the library of higher agricultural colleges serves the rural economic construction, which is the need to adapt to the socialist market economy and realize its own value. At present, although there are many specialized in intelligence agencies and the public library, but they are not as professional as that of the college, the university library has a unique professional literature resources, technology and equipment.

A large number of literature and information resources won't get "activation" and deliver timely, thus reduce the practical and economic value, if university library are not combined closely with the social and economic, with surging literature, increasingly developed information. Only by taking scientific and technological information as the basis, and actively developing, utilizing, and turning it into productive forces, can we benefit from the society of commodity economy and realize the library's own value[2,3].

Secondly, the rural information service is the demand of the rural and farmers. At present, with the development of rural economy and agricultural growth, rural areas and farmers for material, capital and technology investment demand will rapidly increase, the market mechanism to adjust more and more big, rural and farmer's call for technology and information more and more high. That is undoubtedly a great challenge to the current information service of the higher agricultural colleges library, and is a good opportunity to obtain the rapid development of higher agricultural colleges library at the same time, which can promote the information out of the dilemma. The library should seize the opportunity, meet the challenge, give full play to the function of intelligence, and serve the new rural construction better.

\section{Specific Countermeasures for Rural Information Service in Agricultural Colleges and Universities}

With the rapid development of China's economy, the status quo of agricultural colleges and universities library can not meet the demand of the new rural construction, especially the information collection, processing and releasing are faced with many new changes, the object,content, and service methods of information also need to make an adjustment, in order to adapt to the development of new rural construction, concrete countermeasures are as follows:

Provide reference services for farmers. The problem of farmers encountered should be solved at any time for the university library, from the reality of the current rural, in line with the attitude of scientific, practical, innovation. Agriculture experts or staff of agricultural colleges can communicate agricultural technology and issues, and discuss professional information with farmers, rural science and technology workers, and all kinds of technical consultation, through network, onthe-spot investigation. Professional and technical personnel should be sent from the agricultural colleges and universities library, to do the information consulting and knowledge service, for farmers concerned policy and law information, health information, agricultural structure adjustment, market supply and demand information, such as hot topic information, which make farmers get a sense of the economic benefits from the technology information.

Serve the rural informatization construction, rely on remote education. With the development of modern information, the university library can break the traditional short-term training of education, and use its own network platform to remote education for farmers. Through the use of network resources to share the online lectures and upload courseware to the Internet, which can effectively relieve the pressure of education resources in the countryside. Agricultural expert can also be organized by agricultural university library, at the same time, by the way of remote education study of local production, science and technology, decision-making, and being made into video courseware, farmers can browse and download for free at any time to watch, which effectively meet the requirements of the farmers to continue to education. The university library raises the level of scientific and technological information of the peasants through the remote education, which further promotes the industrialization and modernization of the countryside[4]. 
Strengthen agricultural special database construction. With the development of Internet technology, agricultural college library should use its own information resources to establish the most characteristic agricultural database. Agricultural databases is set up for the purpose of shared services, based in the department of agriculture, taking agriculture demand as the main body, the data needed for the agriculture resources is integrated in the form of classification, into a database resources, finally forms the shared service network system. Agricultural characteristic database and thematic database can be established, for example, agricultural resources database, agricultural policies and regulations database, agricultural expert database, database of agricultural production, agricultural wholesale market database[5], agricultural quality standard database, etc. The establishment of the agricultural database will improve the standard of peasants' professional knowledge, play an important role to realize rural resources and intelligence development, improve the decision level of agricultural managers at all levels of government.

Carrying out the activities of scientific and technological information on the Internet to go to the countryside. The agricultural science and technology and agricultural library column is set up on the homepage of the agricultural college library, providing users with free online consultation and a variety of agricultural science and technology information documents, and replying to users' questions in time. This break the limitation of the traditional face to face consultation to the farmers , this is helpful to solve the problem of the user at any timee, and only a few high level personnel is required to solve the user's information technology consulting, which also saves the manpower, material and financial resources for colleges and universities library[6].

Establish the overall sharing of information services and realize the sustainable development of information services. The information service sustainability refers to, the sound information service system, maintenance of measures, guaranteed supply, in order to achieve the effect of long-term service, realize the sustainable development of the information service. The current colleges and universities library literature resources, technology and talents should be effectively integrated at the course of service, formed the multi-level network system of agricultural colleges and universities library. To achieve nationwide literature resources sharing and information service of the overall building, through knowledge and information collecting, organizing, processing and transmission by individual colleges and universities. In the sharing service, we should not be formalistic or fancy[7]. We should sum up the experience and lessons. The whole sharing will promote the sustainable development of the information service in agricultural colleges, and it will positively promote the construction of new socialist countryside directly or indirectly.

Developing personalized information service to enrich the spiritual and cultural life of migrant workers. The CPC central committee and the state council attaches great importance to amateur cultural life of the migrant workers. A lot of colorful cultural activities are launched in many units for migrant workers. The whole society care for migrant workers are gradually formed. However, it is far from enough to solve the spiritual and cultural life of migrant workers, only "sending books" and "sending warm" activities every year. It needs to mobilize the whole society, constructs a plan of systematic, detailed "migrant workers' cultural engineering construction" for the actual needs of migrant workers, for the purpose of long-term, effective solving the cultural life of large number of migrant workers. The agricultural university library is an important part of the social public welfare system, with a large number of agricultural information resources, which should be the leading role in this event. In the work practice, the migrant workers should be the target of service, and the service construction should be strengthened[8].

Improve the service consciousness of the librarians Set up "people-oriented" service concept. The ideas of librarians must be fundamentally changed, new ideas for the needs of farmers be established, and the information literacy of librarians be improved, in the information service of rural areas. It seems that improving librarians' information literacy is a pressing problem, which should be solved through the technology or database training, academic conference, academic activities among colleges and universities, information resources exhibition, the reader training, field research and other activities, consciously strengthening the knowledge, improving the concept 
the librarians, which will improve the information literacy of librarian, promote the healthy development of the agricultural university library.

\section{References}

[1] Z.j.Fan, Cheng letian: policy analysis and field investigation, vol.43 (2013) , p.87-103

[2] D.He:Inner Mongolia science and technology and economy, vol.8(2008),p.146-147

[3] Y.M.Zang :Scientific and technological information, vol. 21(2018),p.168-186

[4]Z.K.Wu:Research on new agricultural science and technology knowledge service system based on farmer's perspective( Ph.D.,China academy of agricultural sciences,China 2012),p.32.

[5]C.C.Zheng: Modern intelligence, vol.32(2012), p.155-158+171

[6]X.Shen: Vicissitudes, vol.2(2011),p.120-121

[7]M.X.Tang:Journal of agricultural book intelligence, vol.2(2009), p.188-189+200

[8]F. Huang :Science and technology information development and economics, vol.10(2005),p.52-53 